\title{
Calcium carbonate production of a dense population of the brittle star Ophiothrix fragilis (Echinodermata: Ophiuroidea): role in the carbon cycle of a temperate coastal ecosystem
}

\author{
A. Migné ${ }^{1, *}$, D. Davoult ${ }^{1, * *}$, J.-P. Gattuso ${ }^{2}$ \\ ${ }^{1}$ Station Marine de Wimereux, Université de Lille 1, EP 1750 CNRS, BP 80, F-62930 Wimereux, France \\ ${ }^{2}$ Observatoire Océanologique, UPRES-A 7076 CNRS-UPMC, BP 28, F-06234 Villefranche-sur-mer Cedex, France
}

\begin{abstract}
The production of calcium carbonate by a dense Ophiothrix fragilis population was calculated in order to investigate its role in the carbon budget of a temperate coastal ecosystem (Dover Strait, eastern English Channel). Production, calculated using monthly data of population density. demographic structure and a size/ $\mathrm{CaCO}$ conversion, was $682 \mathrm{~g} \mathrm{CaCO}_{3} \mathrm{~m}^{-2} \mathrm{yr}^{-1}$ Assuming that the molar ratio of $\mathrm{CO}_{2}$ released to $\mathrm{CaCO}_{3}$ precipitated varied with temperature between 0.66 and 0.73 , this production would result in the release of $4.8 \mathrm{~mol} \mathrm{CO}_{2} \mathrm{~m}^{-2} \mathrm{yr}^{-1}$. This calculation reinforces the suggestion that this coastal system is a source of $\mathrm{CO}_{2}$ to the atmosphere.
\end{abstract}

KEY WORDS: $\mathrm{CO}_{2}$ flux $\cdot \mathrm{CaCO}_{3}$ production $\cdot$ Ophiuroid Coastal ecosystem - Temperate sea

The precipitation of calcium carbonate decreases the concentration of dissolved inorganic carbon (DIC) in seawater by 1 mole for each mole of $\mathrm{CaCO}_{3}$ precipitated (dissolution of $\mathrm{CaCO}_{3}$ has the opposite effect):

$$
\mathrm{Ca}^{2+}+2 \mathrm{HCO}_{3}^{-} \rightarrow \mathrm{CaCO}_{3}+\mathrm{CO}_{2}+\mathrm{H}_{2} \mathrm{O}
$$

Calcification also induces a shift in the seawater carbonate system that generates dissolved $\mathrm{CO}_{2}$. Precipitation of $\mathrm{CaCO}_{3}$ is therefore a source of $\mathrm{CO}_{2}$ in seawater (Ware et al. 1992). The molar ratio ( $\Psi$ ) of $\mathrm{CO}_{2}$ released versus $\mathrm{CaCO}_{3}$ precipitated is 0.6 at $25^{\circ} \mathrm{C}$ for present 'standard' seawater $\left(p \mathrm{CO}_{2}=356 \mu\right.$ atm; total alkalinity $=2370 \mu \mathrm{Eq} \mathrm{kg}{ }^{-1} ; \mathrm{S}=35$ ) (Frankignoulle et al. 1994)

The contribution of $\mathrm{CaCO}_{3}$ precipitation in the carbon cycling of tropical marine ecosystems, mostly coral reefs, has been extensively investigated during the last

\footnotetext{
- Present address: Laboratoire d'Hydrobiologie, Université Paris VI, 12 rue Cuvier, F-75005 Paris, France

-Addressee for correspondence.

E-mail: dom@loalit-univlittoral.fr
}

10 yr (reviewed by Gattuso et al. 1998). Most coral reefs investigated so far have been shown to be sources of $\mathrm{CO}_{2}$ to the atmosphere because, on a $24 \mathrm{~h}$ basis, $\mathrm{CO}_{2}$ release by community calcification is higher than the uptake of $\mathrm{CO}_{2}$ resulting from net community production. Blooms of coccolithophorids, possibly the most important calcifying marine organisms (Westbroek et al. 1989), have also received a lot of attention and have been shown to be net sources of $\mathrm{CO}_{2}$ to the atmosphere (Robertson et al. 1994). The precipitation of $\mathrm{CaCO}_{3}$ has received comparatively much less attention in coastal temperate ecosystems, despite the fact that some of them harbour dense populations of calcifying organisms such as calcareous algae, bryozoans, molluscs or polychaetes (e.g. Smith 1972, Collins 1986). The purpose of this paper is to investigate the role (in terms of $\mathrm{CO}_{2}$ fluxes) of the production of $\mathrm{CaCO}_{3}$ of a dense ophiuroid Ophiothrix fragilis (Abildgaard) population in such a coastal area (Dover Strait. eastern English Channel).

Ophiothrix fragilis is widely distributed in the eastern Atlantic, from northern Norway to the cape of Good Hope (Moyse \& Tyler 1990). It forms dense beds on all coasts of the English Channel, mainly on coarse sediments subject to high tidal currents (Vevers 1952, Cabioch 1968, Cabioch \& Glaçon 1975, 1977), and also on muddy gravels bottoms (Warner 1971). These dense aggregations of this passive suspension-feeder, feeding mainly on phytoplankton (Warner \& Woodley 1975), are assumed to have a significant effect on the exchanges of organic matter at the water-sediment interface (Hily 1991, Davoult et al. 1998). In the Dover Strait, a well-mixed coastal area (Pingree et al. 1975) where tidal currents exceed $2 \mathrm{~m} \mathrm{~s}^{-1}$ in spring tide (Anonymous 1988), the pebble epifaunal community is dominated by this organism at high densities (up to 
2000 ind. $\mathrm{m}^{-2}$; Davoult 1990). The areal extent of the $O$. fragilis population is approximately $600 \mathrm{~km}^{2}$ in the Dover Strait and $5400 \mathrm{~km}^{2}$ in the eastern English Channel (Sanvicente Anorve 1995). $\mathrm{CaCO}_{3}$ production can be calculated using the density of the population, its demographic structure and the relationship of size versus $\mathrm{CaCO}_{3}$ content. The data sets are shown in Table 1. Density data were obtained on samples collected by scuba divers in the Dover Strait from June 1992 to June 1993 (Migné \& Davoult 1997). The station was located in the coastal part of the population $\left(50^{\circ} 55^{\prime} 5 \mathrm{~N} ; 1^{\circ} 34^{\prime} 7 \mathrm{E}\right)$ at a depth of $37 \mathrm{~m}$. Salinity varied from 34.6 to 34.9 (Migné 1996). Size distribution and cohort surveys were made on individuals collected in the same station from February 1987 to March 1988 (Davoult et al. 1990). The size versus $\mathrm{CaCO}_{3}$ content relationship was established for the species by Davoult et al. (1992).

Production of $\mathrm{CaCO}_{3}$ by the Dover Strait Ophiothrix fragilis population (i.e. the sum of production between each sampling period, see Table 1 ) is estimated to be $682 \mathrm{~g} \mathrm{~m}^{-2} \mathrm{yr}^{-1}$. This value is higher than any estimates

Table 1. Mean diameter $(D)$, mean $\mathrm{CaCO}_{3}$ content and density of each cohort for each sampling period in the Dover Strait Ophiothrix fragilis population. The average $\mathrm{CaCO}_{3}$ content was calculated according to the following relationship: $\log \left(\mathrm{CaCO}_{3}\right)=0.258+2.53 \log D($ Davouilt et al. 1992)

\begin{tabular}{|c|c|c|c|}
\hline Period & $\begin{array}{l}\text { Mean diameter } \\
(\mathrm{mm})\end{array}$ & $\begin{array}{c}\text { Mean } \mathrm{CaCO}_{3} \text { content } \\
\left(\mathrm{mg} \mathrm{ind}^{-1}\right)\end{array}$ & $\begin{array}{l}\text { Density } \\
\text { (ind } \mathrm{m}^{-2} \text { ) }\end{array}$ \\
\hline February & $\begin{array}{l}7.4 \\
1.9\end{array}$ & $\begin{array}{r}286.4 \\
9.2\end{array}$ & $\begin{array}{r}1169 \\
81\end{array}$ \\
\hline April & $\begin{array}{l}9.3 \\
3.9 \\
1.2\end{array}$ & $\begin{array}{r}510.5 \\
56.6 \\
2.9\end{array}$ & $\begin{array}{r}747 \\
91 \\
31\end{array}$ \\
\hline May & $\begin{array}{r}10.3 \\
4.9 \\
1.9\end{array}$ & $\begin{array}{r}660.7 \\
100.9 \\
9.2\end{array}$ & $\begin{array}{r}1006 \\
68 \\
68\end{array}$ \\
\hline June & $\begin{array}{r}10.9 \\
7.1 \\
4.1 \\
1.2\end{array}$ & $\begin{array}{r}763.8 \\
258.0 \\
64.3 \\
2.9\end{array}$ & $\begin{array}{r}1117 \\
127 \\
92 \\
78\end{array}$ \\
\hline August & $\begin{array}{r}10.8 \\
7.6 \\
4.2\end{array}$ & $\begin{array}{r}745.7 \\
306.5 \\
68.4\end{array}$ & $\begin{array}{l}943 \\
225 \\
329\end{array}$ \\
\hline September & $\begin{array}{l}9.8 \\
7.7 \\
3.2\end{array}$ & $\begin{array}{r}583.2 \\
316.8 \\
34.4\end{array}$ & $\begin{array}{l}662 \\
190 \\
458\end{array}$ \\
\hline October & $\begin{array}{l}9.7 \\
4.1\end{array}$ & $\begin{array}{r}568.2 \\
64.3\end{array}$ & $\begin{array}{l}662 \\
415\end{array}$ \\
\hline November & $\begin{array}{l}9.7 \\
5.0\end{array}$ & $\begin{array}{l}568.2 \\
106.3\end{array}$ & $\begin{array}{l}900 \\
386\end{array}$ \\
\hline December & $\begin{array}{l}9.2 \\
6.1\end{array}$ & $\begin{array}{l}497.0 \\
175.7\end{array}$ & $\begin{array}{l}892 \\
382\end{array}$ \\
\hline February & $\begin{array}{l}8.9 \\
0.7\end{array}$ & $\begin{array}{r}457.0 \\
0.7\end{array}$ & $\begin{array}{r}1188 \\
62\end{array}$ \\
\hline
\end{tabular}

of carbonate production found in the literature for subtidal macrobenthic communities or populations in temperate ecosystems. Smith (1972) gave subtidal rates of $\mathrm{CaCO}_{3}$ production by calcareous organisms near $400 \mathrm{~g} \mathrm{~m}^{-2} \mathrm{yr}^{-1}$ at 3 localities along the southern California coastline. The major producers of $\mathrm{CaCO}_{3}$ in that hard-bottom environment were bryozoans and coralline algae and, to a lesser extent, echinoderms and molluscs. Medernach (1996) calculated the carbonate production of a polychaete population at different stations (with different densities of the species) in the Bay of Banyuls (Mediterranean Sea, France). She found values varying from $0.7 \mathrm{~g} \mathrm{CaCO}_{3} \mathrm{~m}^{-2} \mathrm{yr}^{-1}$ (for a station with 35 ind. $\mathrm{m}^{-2}$ ) to $397 \mathrm{~g} \mathrm{~m}^{-2} \mathrm{yr}^{-1}$ (for a station with 3550 ind. $\mathrm{m}^{-2}$ ). Collins (1986) estimated a carbonate production of $330 \mathrm{~g} \mathrm{~m}^{-2} \mathrm{yr}^{-1}$ for a deep water Modiolus-brachiopod assemblage from the west coast of Scotland. In this assemblage, $O$. fragilis accounted for $7.4 \%$ of the total biomass (expressed as ash free dry weight) and for $20.9 \%$ of the total $\mathrm{CaCO}_{3}$ production. In that study, $\mathrm{CaCO}_{3}$ production was calculated using an estimate of the production of the population (in terms of ash free dry weight) and a 'standard conversion figure' of 3.46 (our data gave a conversion figure of 2.69). The calculated $\mathrm{CaCO}_{3}$ production rate of the species is on the same order of magnitude in the 2 studies: $445 \mathrm{mg} \mathrm{CaCO} \mathrm{Cnd}^{-1} \mathrm{yr}^{-1}$ according to Collins' data and $541 \mathrm{mg} \mathrm{CaCO}_{3}$ ind. ${ }^{-1} \mathrm{yr}^{-1}$ according to our data. Our estimate of the daily calcification rate is $1.9 \mathrm{~g}$ $\mathrm{CaCO}_{3} \mathrm{~m}^{-2} \mathrm{~d}^{-1}$, a figure that is not negligible compared with the calcification rates reported in the literature for the major calcifying systems. The calcification rates of dense coral communities can be as high as $34 \mathrm{~g} \mathrm{CaCO}_{3}$ $\mathrm{m}^{-2} \mathrm{~d}^{-1}$, but the average calcification rate of entire reef systems is much lower, ca $3 \mathrm{~g} \mathrm{CaCO}_{3} \mathrm{~m}^{-2} \mathrm{~d}^{-1}$ (Gattuso et al. 1998). A rate of calcification of $1.7 \mathrm{~g} \mathrm{CaCO}_{3} \mathrm{~m}^{-2}$ $\mathrm{d}^{-1}$ was observed during the survey of a coccolithophorid bloom in the North East Atlantic (Holligan et al. 1993). Our results confirm that significant $\mathrm{CaCO}_{3}$ deposition can occur in coastal temperate ecosystems, as previously emphasized by Smith (1972). Other temperate systems, such as non exploited formations of maerl (Pinot 1997) or exploitation of oysters or mussels, are also likely sites of elevated rates of calcification.

The ratio of $\mathrm{CO}_{2}$ released to $\mathrm{CaCO}_{3}$ precipitated depends on temperature (Frankignoulle et al. 1994), it varies between 0.66 and 0.73 in the Strait of Dover (Table 2). Calcium carbonate production estimated in the Ophiothrix fragilis population $\left(6.8 \mathrm{~mol} \mathrm{CaCO}_{3} \mathrm{~m}^{-2}\right.$ $\mathrm{yr}^{-1}$ ) would thus result in the release of $4.8 \mathrm{~mol} \mathrm{CO}_{2} \mathrm{~m}^{-2}$ $\mathrm{yr}^{-1}$ (i.e. $58 \mathrm{~g} \mathrm{C} \mathrm{m}^{-2} \mathrm{yr}^{-1}$ ). The role of the $O$. fragilis population in the Dover Strait has already been studied by constructing a model of fluxes and production of organic carbon (Davoult et al. 1998). According to this model, the input of organic carbon into the ' $O$. fragilis 
Table 2. Mean bottom temperature $(T)$ in the Dover Strait and molar ratio of $\mathrm{CO}_{2}$ released versus $\mathrm{CaCO}_{3}$ precipitated $(\psi)$ at each period used for the calculation of $\mathrm{CaCO}_{3}$ production of the Ophiothrix fragilis population. $\psi$ is calculated according to the following relationship: $\psi=0.8-8.3 \times 10^{-3} \mathrm{~T}$ (Frankignoulle et al. 1994)

\begin{tabular}{|lcc|}
\hline Period & Mean bottom temperature $\left({ }^{\circ} \mathrm{C}\right)$ & $\psi$ \\
\hline Feb to Apr & 8.1 & 0.73 \\
Apr to May & 10.8 & 0.71 \\
May to Jun & 13.3 & 0.69 \\
Jun to Aug & 15.9 & 0.67 \\
Aug to Sep & 16.7 & 0.66 \\
Sep to Oct & 15.4 & 0.67 \\
Oct to Nov & 13.3 & 0.69 \\
Nov to Dec & 10.8 & 0.71 \\
Dec to Feb & 8.1 & 0.73 \\
\hline
\end{tabular}

compartment' exceeds local primary production. Input was $635 \mathrm{~g} \mathrm{C} \mathrm{m}^{-2} \mathrm{yr}^{-1}$ (calculated both as the annual fluxes of ingestion and as the sum of annual fluxes of respiration, egestion and production) and phytoplankton primary production was $336 \mathrm{~g} \mathrm{C} \mathrm{m}^{-2} \mathrm{yr}^{-1}$ according to Quisthoudt (1987) or $227 \mathrm{~g} \mathrm{C} \mathrm{m}^{-2} \mathrm{yr}^{-1}$ according to Hoch (1995). Phytoplankton is assumed to be the only primary producer in this area where light limitation (37 $\mathrm{m}$ deep with a high concentration of suspended material) does not allow the development of phytobenthos. It was concluded that this temperate coastal ecosystem is net heterotrophic, since community consumption is apparently larger than gross primary production and the system is thus a potential source of $\mathrm{CO}_{2}$ to the atmosphere. This conclusion, based on the organic carbon budget, is strengthened by the results of the present paper which demonstrate that the calcium carbonate deposition is a significant additional source of $\mathrm{CO}_{2}$ to seawater.

\section{LITERATURE CITED}

Anonymous (1988) Courants de marée dans le Pas de Calais. Service Hydrographique et Océanographique de la Marine, Paris

Cabioch L (1968) Contribution à la connaissance des peuplements benthiques de la Manche occidentale. Cah Biol Mar $9(5): 493-720$

Cabioch L, Glaçon R (1975) Distribution des peuplements benthiques en Manche orientale, de la baie de Somme au Pas de Calais. C R Acad Sci Paris 280(D):491-494

Cabioch L, Glaçon R (1977) Distribution des peuplements benthiques en Manche orientale, du cap d'Antifer à la baie de Somme. C R Acad Sci Paris 285(D):209-212

Collins MJ (1986) Taphonomic processes in a deep water Modiolus-brachiopod assemblage from the west coast of Scotland. PhD dissertation, Univ Glasgow

Davoult D (1990) Biofaciès et structure trophique du peuplement des cailloutis du détroit du Pas de Calais (France) Oceanol Acta 13:335-348

Davoult D, Degros N, Janquin MA, Soyez B (1992) Biometrics, carbon and nitrogen content in the ophiuroid Ophiothrix fragilis. J Mar Biol Assoc UK 72:915-918

Davoult D, Dewailly F, Migné A (1998) Carbon and nitrogen budget of a dense population of the suspension feeding ophiuroid Ophiothrix fragilis in a coastal ecosystem. In: Mooi R, Telford M (eds) Echinoderms: San Francisco. Balkema, Rotterdam, p 337-342

Davoult D, Gounin F, Richard A (1990) Dynamique et reproduction de la population d'Ophiothrix fragilis (Abildgaard) du détroit du Pas de Calais (Manche orientale). J Exp Mar Biol Ecol 138:201-216

Frankignoulle M, Canon C, Gattuso JP (1994) Marine calcification as a source of carbon dioxide: positive feedback of increasing atmospheric $\mathrm{CO}_{2}$. Limnol Oceanogr 39(2): $458-462$

Gattuso JP, Frankignoulle M, Wollast R (1998) Carbon and carbonate metabolism in coastal aquatic ecosystems. Annu Rev Ecol Syst 49:405-433

Hily C (1991) Is the activity of benthic suspension feeders a factor controlling water quality in the bay of Brest? Mar Ecol Prog Ser 69:179-188

Hoch T (1995) Modélisation du cycle biogéochimique des éléments limitant la production biologique en Manche (N, P, Si). Thèse de Doctorat, Univ Paris VII

Holligan PM, Fernandez E, Aiken J, Balch WM, Boyd P, Burkill PH, Finch M, Groom SB, Malin G, Muller K, Purdie $\mathrm{DA}$, Robinson C, Trees CC, Turner SM, van der Wal $P$ (1993) A biogeochemical study of the coccolithophore, Emiliania huxleyi, in the North Atlantic. Global Biogeochem Cycles 7(4):879-900

Medernach L (1996) Répartition géographique et production secondaire de l'annélide polychète Ditrupa arietina (O.F. Muller) le long de la côte catalane française. Rapport de DEA, Univ Paris VI

Migné A (1996) Rôle des organismes suspensivores dans les transferts pelago-benthiques d'une zone de fort hydrodynamisme (détroit du Pas de Calais, Manche orientale): flux et bilan d'azote et de carbone. Thèse de Doctorat, Univ Lille I

Migné A, Davoult D (1997) Distribution quantitative de la macrofaune benthique du peuplement des cailloutis dans le détroit du Pas de Calais (Manche orientale, France). Oceanol Acta 20:453-460

Moyse J, Tyler PA (1990) Echinodermata. In: Hayward PJ, Ryland JS (eds) The marine fauna of the British Isles and North-West Europe. Clarendon Press, Oxford, p 839-871

Pingree RD, Pennycuick L, Gaw B (1975) A time-varying temperature model of mixing in the English Channel. J Mar Biol Assoc UK 55:975-992

Pinot JP (1997) Une biocénose menacée par la surexploitation: le maerl, cas de la baie de Concarneau. In: Dauvin JC (ed) Les biocénoses marines et hittorales françaises des côtes Atlantique, Manche et Mer du Nord: synthèse, menaces et perspectives. Museum National d'Histoire Naturelle, Paris, p 149-158

Quisthoudt C (1987) Production primaire phytoplanctonique dans le détroit du Pas de Calais (France): variations spatiales et annuelles au large du cap Gris-Nez. C R Acad Sci Paris 304(Sér III):245-250

Robertson JE, Robinson C, Turner DR, Holligan P, Watson AJ, Boyd P, Fernandez E, Finch M (1994) The impact of a coccolithophore bloom on oceanic carbon uptake in the northeast Atlantic during summer 1991. Deep-Sea Res 41 : $297-314$

Sanvicente Anorve LE (1995) Détermination des structures benthiques spatiales en Manche orientale au moyen de méthodes d'analyse multivariable et de techniques d'inter- 
polation (exemple de gestion et de traitement d'une base de données en écologie marine). Thèse de Doctorat, Univ Paris VI

Smith SV (1972) Production of calcium carbonate on the mainland shelf of southern California. Limnol Oceanogr $17(1): 28-41$

Vevers HG (1952) A photographic survey of certain areas of sea-floor near Plymouth. J Mar Biol Assoc UK 31:215-221

Ware JR, Smith SV, Reaka-Kudla ML (1992) Coral reefs: sources

Editorial responsibility: Otto Kinne (Editor),

Oldendorf/Luhe, Germany or sinks of atmospheric $\mathrm{CO}_{2}$ ? Coral Reefs 11:127-130

Warner GF (1971) On the ecology of a dense bed of the brittlestar Ophiothrix fragilis. J Mar Biol Assoc UK 51:267-282

Warner GF, Woodley JD (1975) Suspension-feeding in the brittle-star Ophiothrix fragilis. J Mar Biol Assoc UK 55 $199-210$

Westbroek P, Young PR, Linschooten K (1989) Coccolith production (bromineralization) in the marine alga Emiliana huxleyi. J Protozool 36:368-373

Submitted: May 4, 1998; Accepted: September 16, 1998 Proofs received from author(s): October 12, 1998 